Journal of Telenursing (JOTING)

Volume 1, Nomor 2, Desember 2019

e-ISSN: 2684-8988

p-ISSN: 2684-8996

DOI: https://doi.org/10.31539/joting.v1i2.924

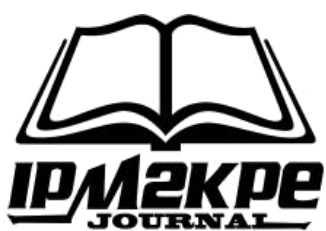

\title{
TERAPI AIUEO TERHADAP KEMAMPUAN BERBICARA (AFASIA MOTORIK) PADA PASIEN STROKE
}

\author{
Ni Made Dwi Yunica ${ }^{1}$, Putu Indah Sintya Dewi ${ }^{2}$ Mochamad Heri ${ }^{3}$, \\ Ni Kadek Erika Widiari ${ }^{4}$ \\ Sekolah Tinggi Ilmu Kesehatan Buleleng ${ }^{1,2,3,4}$ \\ astrianiyunica1@gmail.com ${ }^{1}$
}

\begin{abstract}
ABSTRAK
Tujuan dari penelitian ini yaitu untuk menganalisis pengaruh terapi aiueo terhadap kemampuan berbicara (afasia motorik) pada pasien stroke Di RSU Kertha Usada. Desain penelitian yang digunakan dalam penelitian ini yaitu pra eksperimental dengan rancangan one group pre post test design. Hasil penelitian didapatkan hasil data nilai rata-rata pre 3,61 dan niali rata-rata post 5,21. Hasil uji menggunakan uji Paired t-test didapatkan nilai $\mathrm{p}(0,000)<\alpha(0,05)$. Simpulan, ada pengaruh terapi AIUEO terhadap kemampuan berbicara (afasia motorik) pada pasien stroke di RSU Kertha Usada.
\end{abstract}

Kata Kunci: Kemampuan Berbicara, Terapi AIUEO

\section{ABSTRACT}

The purpose of this study is to analyze the effect of aiueo therapy on speech (motor aphasia) in stroke patients at Kertha Usada General Hospital. The research design used in this study is pre experimental with one group pre post test design. The results of the study obtained the results of the average value of pre 3.61 and the average value of post 5.21. The test results using the Paired t-test obtained $p(0,000)<\alpha(0.05)$. Conclusion, there is an influence of AIUEO therapy on speech (motor aphasia) in stroke patients at Kertha Usada General Hospital.

Keywords: Speech Ability, AIUEO Therapy

\section{PENDAHULUAN}

Stroke merupakan suatu kelainan fungsi otak yang timbul secara mendadak dan terjadi pada siapa saja dan kapan saja. Penyakit ini menyebabkan kecacatan berupa kelumpuhan anggota gerak, gangguan berbicara, gangguan berfikir, emosional (Farida \& Amalia, 2009). Stroke merupakan gangguan yang terjadi pada aliran darah khususnya aliran darah pada pembu-luh arteri otak yang dapat menimbulkan gangguan neurologis. Di Indonesia, diperkirakan setiap tahun sekitar 500.000 penduduk terkena serangan stroke dan sekitar 125.000 orang meninggal dan sisanya mengalami cacat ringan atau berat (Yastroki, 2011).

Menurut World Health Organization (WHO) tahun 2018 stroke merupakan salah satu masalah kesehatan yang utama didunia. Stroke menempati peringkat ketiga penyebab kematian, pada tahun 2013 terdapat 5,5 juta orang meninggal dan meningkat sebanyak 12\% pada tahun 2018 yaitu sekitar 14 juta orang (WHO, 2018). 
Hasil dari Riskesdas (2018) menunjukkan telah terjadi peningkatan prevalensi stroke di Indonesia dari 7\% (2013) menjadi 10.9\% (2018). WHO memperkirakan pada tahun 2020 7,6 juta orang akan meninggal dikarenakan penyakit ini. Jumlah penderita stroke usia 45-54 sekitar $8 \%$, kasus stroke tertinggi yang terdiagnosis tenaga kesehatan adalah usia 75 tahun keatas $(43,1 \%)$ dan terendah pada kelompok usia 15-24 tahun yaitu sebesar $0,2 \%$. Prevalensi stroke berdasarkan jenis kelamin lebih banyak laki-laki $(7,1 \%)$ dibandingkan dengan perempuan (6,8\%) (Farida \& Amalia, 2009).

Stroke atau cedera serebrovaskular karena kehilangan fungsi otak yang diakibatkan oleh berhentinya suplai darah ke bagian otak yang dikarenakan pecahnya pembuluh darah. Penyebab penyakit stroke salah satunya karena tingginya tekanan darah, akibat lebih tinggi tekanan darah, lebih besar jumlah kerusakan vascular dan dapat memicu pecahnya pembuluh darah (Padila, 2012). Penyebab stroke adalah perdarahan dari pembuluh darah di otak atau dari gumpalan darah. Stroke memiliki gejala seperti rasa lemas tiba-tiba dibagian tubuh; wajah, lengan, atau kaki seringkali terjadi pasa salah satu sisi tubuh, kesulitan bicara atau memahami pembicaraan, kesulitan melihat dengan satu mata atau kedua mata, kesulitan berjalan,pusing, hilang keseimbangan, sakit kepala parah tanpa penyebab jelas dan hilang kesadaran atau pingsan (Kementrian Kesehatan RI, 2013).

Melihat banyaknya kejadian stroke setiap tahunnya, perlu dilakukan penanganan dengan segera, mengingat dampak dari stroke yang sangat merugikan. Dampak stroke yang paling umum antara lain kelumpuhan anggota gerak, wajah perot atau face drooping, gangguan penglihatan, gangguan menelan, gangguan sensasi raba, dan gangguan bicara atau afasia (Pinzon et al., 2010).

Gangguan fungsi saraf lokal dan atau global, secara mendadak, progresif dan cepat adalah ciri khas penyakit stroke. Gangguan fungsi saraf pada stroke disebabkan oleh gangguan peredaran darah otak non traumatik maupun traumatik. Gangguan saraf tersebut menimbulkan gejala antara lain : kelumpuhan wajah atau anggota badan, bicara tidak lancar, bicara tidak jelas (pelo), mungkin perubahan kesadaran, gangguan penglihatan, dan lain-lain (Riscther, 2015).

Masalah kesehatan yang muncul dari serangan penyakit stroke sangat bervariasi tergantung luas daerah otak yang mengalami infrak atau kematian jaringan dan lokasi yang terkena (Kusumo \& Sudi, 2009). Bila stroke menyerang otak kiri dan mengenai pusat bicara, kemungkinan pasien akan mengalami gangguan bicara atau afasia, karena otak kiri berfungsi untuk menganalisis, pikiran logis, konsep, dan memahami bahasa (Farida \& Amalia, 2009). Secara umum afasia dibagi menjadi 3 yaitu afasia motorik, afasia sensorik dan afasia global.

Orang yang mengalami gangguan bicara atau afasia akan mengalami kegagalan dalam berartikulasi. Artikulasi merupakan proses penyesuaian ruangan supraglottal. Penyesuaian ruangan didaerah laring terjadi dengan menaikkan dan menurunkan laring, yang akan mengatur jumlah transmisi udara melalui rongga mulut dan rongga hidung melalui katup velofaringeal dan merubah posisi mandibula (rahang bawah) dan lidah. Proses diatas yang akan menghasilkan bunyi dasar dalam berbicara (Yanti, 2012).

Afasia memberikan dampak pada berbagai aspek kehidupan. Terutama pada kesejahteraan pasien, kemandirian, partisipasi sosial, dan kualitas hidup pasien. Dampak ini muncul diakibatkan komunikasi yang tidak adekuat antara pasien dan lingkungan. Kondisi mortilitas yang tinggi dan kemampuan fungsional yang rendah pada pasien afasia dapat terjadi karena pasien tidak mampu mengungkapkan apa yang pasien inginkan, tidak mampu menjawab pertanyaan atau berpartisipasi dalam percakapan. 
Ketidakmampuan ini menyebabkan pasien men-jadi frustasi, marah, kehilangan harga diri, dan emosi pasien menjadi labil yang pada akhirnya dapat menyebabkan pasien menjadi depresi (Mulyatsih \& Ahmad, 2010).

Afasia motorik merupakan kerusakan terhadap seluruh korteks pada daerah broca. Seseorang dengan afasia motorik tidak bisa mengucapkan satu kata apapun, namun masih bisa mengutarakan pikirannya dengan jalan menulis (Wiwit, 2010). Salah satu bentuk terapi rehabilitasi gangguan afasia adalah dengan memberikan terapi wicara (Wiwit, 2010). Terapi wicara merupakan tindakan yang diberikan kepada individu yang mengalami gangguan komunikasi, gangguan berbahasa bicara, gangguan menelan. Salah satu terapiwicara yang dapat diberikan untuk pasien stroke dengan gangguan berbicara adalah terapi AIUEO (Wiwit, 2010).

Salah satu bentuk terapi rehabilitasi gangguan afasia adalah dengan memberikan terapi AIUEO. Terapi AIUEO bertujuan untuk memperbaiki ucapan supaya dapat dipahami oleh orang lain. Orang yang mengalami gangguan bicara atau afasia akan mengalami kegagalan dalam berartikulasi. Artikulasi merupakan proses penyesuaian ruangan supraglottal. Penyesuain ruangan didaerah laring terjadi dengan menaikkan dan menurunkan laring, yang akan mengatur jumlah transmisi udara melalui rongga mulut dan ronggahidung melalui katup velofaringeal dan merubah posisi mandibula (rahang bawah) dan lidah. Proses diatas yang akan menghasilkan bunyi dasar dalam berbicara (Yanti, 2012).

Jumlah pasien stroke yang mengalami kejadian afasia sulit didapat di buku, jurnal dan e-jurnal. Afasia memiliki klasifikasi yang dikelompokkan berdasarkan pada manifestasi kliniknya afasia dibagi menjadi afasia lancar dan afasia tidak lancar. Afasia lancar meliputi ; afasia sensorik (wernicke), afasia konduksi, afasia amnesik (anomik) dan afasia transkortikal sensorik. Afasia tidak lancar meliputi: afasia motorik (broca), afasia global dan afasia transkortikal motorik (Satyanegara, 2010).

Afasia motorik atau afasia broca merupakan bentuk afasia yang paling sering dijumpai. Gejala berupa bicara tidak lancar, disartia serta nampak melakukan upaya bila hendak berbicara. Repitisi dan membaca kuat sama terganggunya seperti berbicara spontan. Pemahaman kalimat dengan tata bahasa yang komplaks sering terganggu (Satyanegara, 2010).

Afasia merusak kemampuan pasien untuk berkomunikasi, baik dalam memahami apa yang dikatakan dan dalam kemampuan mengeskresikan diri sendiri (Bare et al., 2002). Stressor tersebut menyebabkan hilangnya peran hidup yang dimiliki penderita stroke hingga terjadinya gangguan persepsi akan konsep diri yang bersangkutan dan dengan sendirinya mengurangi kualitas hidup pasien stroke (Hayulita \& Sari 2015).

Penelitian yang dilakukan oleh Wardhana (2011) menunjukkan ada pengaruh terapi AIUEO terhadap kemampuan bicara pasien stroke yang mengalami afasia motorik. Pasien stroke yang mengalami kondisi ini dapat diberikan terapi AIUEO yang bertujuan untuk memperbaiki ucapan supaya dapat dipahami oleh orang lain.

Terapi AIUEO merupakan terapi yang bertujuan untuk memperbaiki ucapan supaya dapat dipahami oleh orang lain dengan cara menggerakan lidah, bibir, otot wajah, dan mengucapkan kata-kata (Wardhana, 2011; Wiwit, 2010). Metode yang digunakan dalam terapi AIUEO yaitu dengan metode imitasi, di mana setiap pergerakan organ bicara dan suara yang dihasilkan perawat diikuti oleh pasien (Gunawan, 2008).

Menurut Wiwit (2010) penderita stroke yang mengalami kesulitan bicara akan diberikan terapi AIUEO yang bertujuan untuk memperbaiki ucapan supaya dapat dipahami oleh orang lain. Orang yang mengalami gangguan bicara atau afasia akan 
mengalami kegagalan dalam berartikulasi. Artikulasi merupakan proses penyesuaian ruangan supraglottal. Penyesuaian ruangan didaerah laring terjadi dengan menaikkan dan menurunkan laring, yang akan mengatur jumlah transmisi udara melalui rongga mulut dan rongga hidung melalui katup velofaringeal dan merubah posisi mandibula (rahang bawah) dan lidah. Proses diatas yang akan menghasilkan bunyi dasar dalam berbicara (Rusyani, 2009).

\section{METODE PENELITIAN}

Penelitian ini menggunakan penelitian pre eksperimental, karena dalam penelitian memberikan perlakuan atau intervensi pada objek yang akan diteliti. Desain yang digunakan dalam penelitian ini yaitu one group pre-test dan post-test, dimana objek yang akan diteliti sebelum diberikan perlakuan dilakukan pre-test terlebih dahulu dan setelah diberikan perlakuan atau intervensi akan dilakukan post-test. Penelitian ini dilakukan di RSU Kertha Usada. Sampel penelitian ini adalah pasien stroke yang mengalami gangguan berbicara yang sudah memenuhi kriteria inklusi yang berjumlah 28 orang

\section{HASIL PENELITIAN}

Tabel. 1

Karakteristik Responden Berdasarkan Kelompok Umur

\begin{tabular}{cccc}
\hline Variabel & Kategori & Jumlah & $\%$ \\
\hline Usia & Dewasa Awal & 2 & 7.1 \\
& Dewasa Akhir & 0 & 0 \\
& Lansia Awal & 3 & 10.7 \\
& Lansia Akhir & 10 & 35.7 \\
& Manula & 13 & 46.7 \\
\hline Total & & 28 & 100
\end{tabular}

Berdasarkan tabel 1 menunjukkan bahwa sebagian besar penderita stroke adalah usia manula sebanyak 13 orang $(46,7 \%)$.

Tabel. 2

Karakteristik Responden Berdasarkan Jenis Kelamin

\begin{tabular}{lccc}
\hline Variabel & Kategori & Jumlah & $\%$ \\
\hline Jenis Kelamin & Laki-laki & 21 & 75 \\
& Perempuan & 7 & 25 \\
\hline Total & & 28 & 100 \\
\hline
\end{tabular}

Berdasarkan tabel 2 menunjukkan bahwa penderita stroke paling banyak adalah laki-laki 21 orang $(75 \%)$. 
Tabel. 3

Skor Pre Test DFCS pada Pasien Stroke dengan Gangguan Berbicara

\begin{tabular}{cccccc}
\hline & N & Mean & Min & Max & SD \\
\hline Pretest & 28 & 3.61 & 1 & 7 & 1.449 \\
\hline
\end{tabular}

Berdasarkan tabel 3 didapatkan bahwa hasil rerataan kemampuan berbicara pada pasien stroke adalah 3,61 dengan nilai paling tinggi adalah 7 dan terendah adalah 1 .

Tabel. 4

Skor Post Test DFCS pada Pasien Stroke

dengan Gangguan Berbicara

\begin{tabular}{lccccc}
\hline & N & Mean & Min & Max & SD \\
\hline Post-test & 28 & 5.21 & 3 & 7 & 1.343
\end{tabular}

Berdasarkan tabel 4 didapatkan bahwa rerataan kemampuan berbicara setelah diberikannya intervensi adalah 5.21 dengan nilai minimum 3 dan maximum 8 .

Tabel. 5

Hasil Uji Pre dan Post Test dengan

Menggunakan Uji Paired t-test

\begin{tabular}{cccccc}
\hline $\mathrm{n}$ & Mean & SD & Std. Eror mean & df & Sig (2-tailed) \\
\hline 28 & 1.607 & 0.629 & 0.119 & 27 & 0.000 \\
\hline
\end{tabular}

Berdasarkan tabel 5 menunjukan bahwa hasil analisis Paired T Test didapatkan $p$ value $0,000(\mathrm{p}<0,05)$ yang berarti bahwa Ho ditolak dan Ha diterima, menunjukan ada pengaruh terapi AIUEO terhadap kemampuan berbicara pada pasien stroke yang mengalami gangguan berbicara.

\section{PEMBAHASAN}

Berdasarkan tabel 1 menunjukan bahwa sebagian besar penderita stroke adalah usia manula. Hasil dari penelitian ini sama dengan hasil penelitian (Muhrini et al., 2012) bahwa kebanyakan stroke diderita oleh orang berusia $>55$ tahun. Semakin tua seseorang maka semakin tinggi juga resiko untuk terkena penyakit stroke (Farida \& Amalia, 2009). Pendapat tersebut didukung oleh penelitian Dwi et al., (2014) disimpulkan bahwa usia responden yang menderita stroke yaitu rentang 55-65 tahun. Kemampuan berbicara mulai mengalami peningkatan pada hari ketiga setelah diberikan terapi AIUEO. Pengaruh terapi AIUEO menjadi bermakna dalam meningkatkan kemampuan berbicara dimulai pada. Hasil penelitian tersebut berbanding lurus dengan teori lain yang menyatakan bahwa resiko kejadian stroke terjadi pada usia lebih dari 55 tahun dan meningkat 2 kali lipat setiap dekade (Misbach, 2011).

Cedal atau pelo juga sering kita dengar pada orang dengan usia tua. Cakraborty dalam Rosdiana (2012) menyatakan bahwa mayoritas pasien yang menderita disartria pada rentang usia dewasa tengah. Dalam penelitian ini didapatkan rata-rata yang mengalami disartria adalah usia lanjut. Elastisitas pembuluh darah pada usia tersebut 
menurun mengakibatkan banyaknya timbunan plak, sehingga menyebabkan aterosklerosis. Aterosklerosis sendiri dapat menyebabkan masalah pada pembuluh darah di jantung dan otot jantung (Rosdiana, 2012). Pasien yang berusia tua memiliki faktor resiko stroke maka semakin besar juga peluang untuk stroke dan apabila terkena bagian otak yang berperan pada otot-otot bicara dan saraf bicara, maka besar kemungkinan menderita disartria.

Berdasarkan tabel 2 menunjukan bahwa penderita stroke paling banyak adalah laki-laki. Penelitian yang dilakukan oleh Muhrini et al., (2012) menunjukan bawa lakilaki lebih beresiko terkena penyakit stroke dan perempuan lebih rendah. Laki-laki lebih beresiko terkena penyakit stroke karena faktor resiko tambahan yang dapat meningkatkan resiko terkena penyakit pada laki-laki salah satunya adalah life style, merokok dan minum-minuman beralkohol far (Farida \& Amalia, 2009).

Penelitian yang dilakukan Rosdiana (2012) didapatkan hasil bahwa lebih banyak wanita yang mengalami kerusakan komunikasi verbal. Hal ini berbanding terbalik dengan hasil penelitian kali ini. dimana jenis kelamin laki-laki yang mengalami disartria. Demikian pula hasil penelitian Amila et al., (2013) menyatakan bahwa sebagian besar kerusakan komunikasi verbal pada responden laki-laki. Laki-laki memiliki kebiasaan merokok atau kebiasaan hidup tidak sehat dengan makan-makanan berlemak yang menyebabkan aterosklerosis pada pembuluh darah. Aterosklerosis pada pembuluh darah dapat mengakibatkan sumbatan pada aliran darah, akibatnya terjadi emboli, thrombus maupun hipoperfusi sistemik. Semua hal tersebut menyebabkan terjadi iskemia di otak hingga stroke. Iskemia di otak mengakibatkan kerusakan pada bagian pons atau medulla oblongata mengakibatkan disartria.

Orang yang mengalami gangguan bicara atau afasia akan mengalami kegagalan dalam berartikulasi. Artikulasi merupakan proses penyesuaian ruangan supraglottal. Penyesuaian ruangan didaerah laring terjadi dengan menaikkan dan menurunkan laring, yang akan mengatur jumlah transmisi udara melalui rongga mulut dan rongga hidung melalui katup velofaringeal dan merubah posisi mandibula (rahang bawah) dan lidah. Proses diatas yang akan menghasilkan bunyi dasar dalam berbicara (Yanti, 2012).

Penelitian sebelumnya Dwi et al., (2014) yang mendapatkan bahwa ada pengaruh terapi AIUEO terhadap kemampuan bicara pasien stroke yang mengalami afasia motorik. Hal ini juga diperkuat oleh penelitian Sofiatun et al., (2014) yang membandingkan terapi AIUEO dan terapi the token test mendapati bahwa terapi AIUEO lebih efektif diberikan kepada pasien stroke yang mengalami gangguan berbicara.

Penelitian ini serupa dengan penelitian yang dilakukan oleh Prihatin et al., (2017) yang membedakan terapi MIT dan terapi AIUEO yang menyatakan bahwa terapi AIUEO lebih efektif terhadap waktu kemampuan berbicara pada pasien stroke dengan afasia motorik di RS Panti Wilasa Citarum Semarang. Penelitian yang dilakukan oleh Suharti et al., (2016) didapatkan bahwa terapi bicara yang dilakukan dengan rutin dapat meningkatkan kemampuan berbicara pada pasien stroke yang mengalami gangguan berbicara. Penelitian ini juga sejalan dengan penelitian yang dilakukan oleh Puspitasari et al., (2017) yang menyatakan bahwa ada pengaruh terapi AIUEO terhadap kemampuan komunikasi pasien afasia motorik pasca stroke di Kota Pontianak.

Hasil penelitian ini sejalan dengan penelitian Dwi et al., (2014) menunjukkan bahwa terdapat peningkatan terapi wicara AIUEO pada pasien dengan afasia motorik dengan $p$ - value 0,000. Responden lebih efektif diberikan terapi AIUEO karena responden lebih mudah untuk menirukan pembentukan vokal, gerak lidah bibir, rahang. Terapi AIUEO merupakan tindakan yang diberikan kepada individu yang mengalami 
gangguan komunikasi. gangguan bahasa dan gangguan bicara yang dibahas berfokus pada terapi bicara pada pasien dengan masalah-masalah dengan neurologis, di antaranya pasca stroke.

Pengulangan bunyi masing-masing alfabet sebagai awal pelatihan kembali dapat diupayakan pada penderita stroke sedini mungkin sejak terdeteksi mengalami afasia (Hudak \& Barbara, 2010). Terapi AIUEO adalah terapi yang menggunakan teknik mengajarkan pasien afasia menggerakkan otot bicara melalui menggerakan lidah bibir otot wajah dan mengucapkan kata-kata dengan fonem bahasa A,I,U,E,O. Terapi AIUEO merupakan jenis terapi wicara yang dikenal bagian dari phonomotor therapy. Sejalan dengan penelitian yang dilakukan oleh Bose (2013) membuktikan bahwa terdapat perubahan signifikan pada kemampuan penderita aphasia jargon/anomik dalam menamai benda.

Pasien stroke yang sering mengalami gangguan bicara dan komunikasi, dapat ditangani salah satunya dengan cara, latihan di depan cermin untuk latihan gerakan bibir, lidah, dan mengungkapkan kata-kata. Teknik yang diajarkan pada afasia adalah menggerakkan otot bicara yang akan digunakan untuk mengucapkan lambang- lambang bunyi bahasa yang sesuai dengan pola-pola standar, sehingga dapat dipahami oleh pasien. Hal ini disebut artikulasi organ bicara. Pengartikulasian bunyi bahasa atau suara akan dibentuk oleh koordinasi tiga unsur yaitu unsur motoris (pernafasan), unsur yang bervibrasi (tenggorokan dengan pita suara), dan unsur yang beresonansi (rongga hidung, mulut, dan dada) (Gunawan, 2008).

Latihan pembentukan vokal terjadi dari getaran selaput suara dengan nafas keluar mulut tanpa mendapat halangan. Dalam sistem fomen bahasa indonesia, vokal terdiri dari A, I, U, E, dan O. Dalam pembentukan vokal yang penting diperhatikan adalah letak dan bentuk lidah, bibir, rahang, dan langit-langit lembut (velum) (Gunawan, 2008). Hal ini juga diperkuat Wiwit (2010) pasien stroke yang mengalami gangguan bicara dan komunikasi, salah satunya dapat ditangani dengan cara terapi AIUEO untuk menggerakkan lidah, bibir, otot wajah dan mengucapkan kata-kata. Latihan terapi the token test lebih sulit diterima oleh responden, karena pusat berbahasa berada pada area broca dan wernick. Kedua pusat ini berhubungan erat, sehingga memungkinkan responden meniru apa yang diucapkan oleh peneliti. Di lobus parietalis kiri pada perbatasan dengan lobus oksipitalis, terdapat pusat ingatan benda-benda yang menyimpan nama benda bersangkutan, sehingga bila terjadi kerusakan akan terjadi kehilangan daya ingat nama benda yang dilihat. Pada kerusakan di daerah perbatasan lobus oksipitalis dengan lobus temporalis, responden tetap tidak dapat mengatakan nama benda yang diperlihatkan, meskipun diberikan bantuan dengan memberi suku kata nama benda tersebut (Markam, 2009).

\section{SIMPULAN}

Berdasarkan pemaparan hasil penelitian pengaruh terapi AIUEO terhadap kemampuan berbicara (afasia motorik) pada pasien stroke di RSU Kerta Usada, dapat disimpulkan beberapa hal sebagai berikut.

Dari 28 subjek penelitian, distribusi frekuensi pasien berdasarkan usia ditemukan bahwa pasien paling banyak berada pada usia manula. Berdasarkan jenis kelamin didapatkan pasien mayoritas adalah laki-laki.

Hasil uji yang dilakukan dengan mengunakan uji paired t-test menunjukan bahwa terdapat pengaruh pemberian terapi AIUEO terhadap kemampuan berbicara (afasia motorik) pada pasien stroke di RSU Kertha Usada. 


\section{SARAN}

Hasil penelitian ini mendapatkan bahwa terdapat pengaruh yang signifikan dari Terapi AIUEO terhadap Kemampuan Berbicara (Afasia Motorik) pada Pasien Stroke di RSU Kertha Usada

\section{Bagi Institusi Tempat Penelitian}

Hasil penelitian ini dapat menjadi bahan masukan bagi institusi tempat penelitian, guna meningkatkan pelayanan dalam lingkup keperawatan medikal bedah.

\section{Bagi Institusi Pendidikan}

Hasil penelitian ini dapat digunakan dalam pengembangan ilmu keperawatan dan sebagai pedoman dalam pembelajaran untuk meningkatkan pengetahuan dan kemampuan peserta didik, khususnya mahasiswa keperawatan.

\section{Bagi Peneliti Selanjutnya}

Hasil penelitian ini dapat digunakan peneliti selanjutnya sebagai acuan untuk melakukan riset lebih lanjut mengenai "Pengaruh Terapi AIUEO terhadap Kemampuan Berbicara (Afasia Motorik) pada Pasien Stroke di RSU Kertha Usada"

\section{DAFTAR PUSTAKA}

Amila, A., Sitorus, R., \& Herawati, T. (2013). Pengaruh Augmentative and Alternative Communication terhadap Komunikasi dan Depresi Pasien Afasia Motorik. Jurnal Keperawatan Padjajaran, 1(3), 131-143. https://doi.org/10.24198/jkp.v1i3.61. http://jkp.fkep.unpad.ac.id/index.php/jkp /article/viewFile/61/58

Bare, B. G., Smeltzer, C. S., Brunner, B., \& Suddarth, S. (2002). Buku Ajar Keperawatan Medikal Bedah. Jakarta: EGC

Bose, A. (2013). Phonological Therapy in Jargon Aphasia: Effects on Naming and Neologisms. INTERNATIONAL Journal of Language and Communication Disorder, 48(5), 582-595. Doi : 10.1111/1460-6984.12038

Dwi, G., Haryanto, A., Setyawan, D., Argo, M., \& Kusuma, B. (2014). Pengaruh Terapi AIUEO terhadap Kemampuan Berbicara Pasien Stroke yang Mengalami Afasia Motorik di RSUD Tugurejo Semarang, 1-11. Retrieved from.http://ejournal.stikestelorejo.ac.id/index.php/ilmukeperawatan/article/view/2 17

Farida, I., \& Amalia, N. (2009). Mengantisipasi Stroke Petunjuk Mudah, Lengkap, dan Praktis Sehari-Hari. (A.S.Sujatna, Ed.). Jogjakarta: Buku Biru

Gunawan, D. (2008). Buku Artikulasi. Universitas Pendidikan Indonesia

Hayulita, S., \& Sari, D. R. (2015). Faktor-Faktor yang Berhubungan dengan Depresi pada Pasien Paska Stroke di Ruang Rawat Jalan Rumah Sakit Stroke Nasional (RSSN) Bukittinggi. Jurnal Ilmu Kesehatan 'Afiyah, 2(1)

Hudak, C. M., \& Barbara M. G. (2010). Keperawatan Kritis: Pendekatan Holistik. Ed.6. Jakarta: EGC

Kemenkes RI. (2013). Riset Kesehatan Dasar; RISKESDAS. Jakarta: Balitbang Kemenkes RI

Kusumo, S., \& Sudi, L. D. S. (2009). Afasia Gangguan Berkomunikasi Pasca Stroke. Jakarta: Universitas Indonesia

Markam, R. S. (2009). Penuntun Neurologi. Tangerang: Binarupa Aksara Publizer

Misbach, J. (2011). Stroke Aspek Diagnostik, Pathofisiologi, Manajemen. Jakarta: Balai penerbit FKUI 
Muhrini, A., Ika, S., Sihombing, Y., \& Hamra, Y. (2012). Hubungan Umur, Jenis Kelamin dan Hipertensi dengan Kejadian Stroke, 24-30. Retrieved from file://C:/Users/compaq/Downloads/182-514-1-PB (1).pdf

Mulyatsih, E., \& Ahmad, A. A. (2010). Stroke: Petunjuk Perawatan Pasien Pasca Stroke di Rumah. Jakarta: Balai Penerbit FK UI

Padila, P. (2012). Buku Ajar Keperawatan Medikal Bedah. Yogyakarta: NuhaMedika

Pinzon, R., Laksmi, A., Sugianto, S., \& Kriswanto, W. (2010). Awas Stroke! Pengertian, Gejala, Tindakan, Perawatan, dan Pencegahan. Yogyakarta: ANDI OFFSET

Prihatin, L. W., Kristiyawati., \& Asri, P. (2017). Perbedaan Efektifitas Terapi AIUEO dan Melodic Intonation Therapy (MIT) terhadap Waktu Kemampuan Bicara pada Pasien Stroke dengan Afasia Motorik di Rumah Sakit Panti Wilasa Citarum Semarang. Retrieved from http://182.253.197.100/ejurnal/index.php/ilmukeperawatan/article/download/217/242

Puspitasari, D., Kusuma, K., \& Fahdi, F. K. (2017). Pengaruh Terapi AIUEO terhadap Kemampuan Komunikasi pada Afasia Motorik Pasien Pasca Stroke di Kota Pontianaki. Naskah Publikasi. Universitas Tanjungpura Pontianak

Riscther, A., Lewin, V, M., Jobges, M., \& Werheid, K. (2015). Predictivity of Early Depressive Symptoms for Post-Stroke Depression. Journal Nutrition Health Aging; Clinical Neuroscience, 19(7)

Riskesdas. (2018). Hasil Utama Riskesdas 2018 Kesehatan, Kementerian. Retrieved from http://www.depkes.go.id/resources/download/infoterkini/materi_rakorpop_2018/Hasil Riskesdas 2018.pdf

Rosdiana, N. (2012). Pengaruh Latihan NS-OMTs: Blowing Pipe terhadap Kemampuan Komunikasi Verbal Pasien Stroke dengan Dysarthria di RSUD Banjar, Ciamis dan Tasikmalaya.lib.ui.ac.id/file?file $=$ digital/20297849T29793\%20Pengaruh\%20latih an.pdf

Sofiatun, I., Kristiyawati, S. P., \& Purnomo, S. E. C. (2014). Efektifitas Terapi AIUEO dan Terapi The Token Test terhadap Kemampuan Berbicara Pasien Stroke yang Mengalami Afasia Motorik di RS Mandiri Rahayu Kudus, 230-238. Retrieved. http://ejournal.stikestelogorejo.ac.id/index.php/jikk/article/download/377/398

Rusyani, D. E. (2009). Konsep Dasar Artikulasi dan Oprimalisasi Fungsi Pendengaran, $1-120$

Sanjaya, N. A. (2015). Gangguan Fonologi Keluaran Kemampuan Wicara pada Penderita Afasia Broca dan Afasia Wernicke Suatu Kajian Neurololinguistik. Retrieved. from.http://jurnal.unj.id/index.php/arkhais/article/download/367/311

Satyanegara, S. (2010). Ilmu Bedah Saraf. Edisi 4. Jakarta: Gramedia Pustaka Utama

Suharti, S., Munifatul, S., Ariyani, T., \& Haryono, W. (2016). Efektifitas Penggunaan Cermin terhadap Kemampuan Bicara pada Pasien Stroke dengan Afasia Motorik Di SMC RS Telogorejo. Jurnal Ilmu Keperawatan dan Kebidanan, 8(3), Retrieved from http://ejournal.stikestelogorejo.ac.id?index.php/jikk/article/view/389

Wardhana, W. A. (2011). Strategi Mengatasi \& Bangkit dari Stroke. Yogyakarta: Pustaka Pelajar

World Health Organization (WHO). (2018). Stroke, Cerebrovascular Accident. Diambil dari http://www.who.int/topics/cerebrovascular_accident/en/

Wiwit, S. (2010). Sroke \& Penangananya. (M. Sandra, Ed.). Jogjakarta: Kata Hati

Yanti, D. (2012). Penatalaksanaan Terapi Wicara pada Tuna Rungu. Akrab: ECG 
2019. Journal of Telenursing (JOTING) 1 (2) 396-405

Yastroki, S. (2011). Stroke Penyebab Kematian Urutan Pertama di Rumah Sakit di Indonesia. Diperoleh dari http://www.yastroki.or.id 